\title{
A survey of Senecio spp. affecting livestock in Uruguay and their associated pyrrolizidine alkaloid content
}

\author{
Juan Agustín García ${ }^{1 *}$ Carmen García y Santos ${ }^{2}$ \\ Juan Rosas ${ }^{3}$ Fernando Dutra ${ }^{4}$ Dale Gardner ${ }^{5}$
}

\author{
${ }^{1}$ Centro Universitario Regional Este, Universidad de la República, R8 km 282, Treinta y Tres (33000), Uruguay. E-mail: garciajuanagustin89@ \\ gmail.com. "Corresponding author. \\ ${ }^{2}$ Departamento de Toxicología, Facultad de Veterinaria, Universidad de la República, Montevideo, Uruguay. \\ ${ }^{3}$ Instituto Nacional de Investigación Agropecuaria, Treinta y Tres, Uruguay. \\ ${ }^{4}$ DILAVE “Miguel C Rubino" Regional Este, Treinta y Tres, Uruguay. \\ ${ }^{5}$ USDA, ARS, Poisonous Plant Research Laboratory, Utah, USA.
}

\begin{abstract}
In Eastern Uruguay there has been a significant increase of seneciosis in grazing livestock with most affected localities related to counties neighboring the Brazilian border. A survey in 28 farms associated with poisoning outbreaks in grazing cattle in Eastern Uruguay was carried out. Fifty populations of Senecio plants were collected for alkaloid analysis and species identification. Four species were identified: S. oxyphyllus DC, S. madagascariensis Poir, S. brasiliensis (Spreng.) Less., and S. selloi DC. Alkaloids were identified by a combination of GC-MS and HPLC-MS analysis and included: retrorsine in S. oxyphyllus; retrorsine, usaramine, and senecivernine/senecionine in S. selloi; retrorsine, senecivernine/senecionine, integerrimine, and usaramine in S. madagascariensis; and integerrimine, retrorsine and senecionine in S. brasiliensis. Total mean alkaloid concentration was reported to be highest in S. brasiliensis (17.6mg/g) followed by S. oxyphyllus (6.2mg/g), S. selloi $(1.8 \mathrm{mg} / \mathrm{g})$ and S. madagascariensis $(0.6 \mathrm{mg} / \mathrm{g})$. Alkaloid concentrations were also reported to be higher in $2015 \mathrm{vs}$. 2016 probably due to a common environmental factor. The species S. oxyphyllus and S. madagascariensis were not previously recognized as toxic plants in Eastern Uruguay. Particularly, S. oxyphyllus was present in $82 \%$ of the farms surveyed and occurred in high density with relative high concentrations of pyrrolizidine alkaloids suggesting $S$. oxyphyllus may be the main species involved in the reported outbreaks of seneciosis.

Key words: seneciosis, plant secondary metabolites, ruminants, poisonous plants, Asteraceae.
\end{abstract}

Senecio spp. Afetando a pecuária no Uruguai e sua associação com alcaloides pirrolizidínicos

RESUMO: No leste do Uruguai houve um aumento significativo da seneciosis no gado de pastagem com a maioria das localidades afetadas em municípios vizinhos à fronteira brasileira. Aplicou-se um questionário em 28 fazendas associadas a surtos de intoxicação em bovinos de pastagem na fronteira leste do Uruguai. Coletaram-se cinquenta populações de Senecio para análise de alcalóides e identificação de espécies. Identificaram-se quatro espécies: S. oxyphyllus DC, S. madagascariensis Poir, S. brasiliensis (Spreng.) Less. e S. selloi DC. Identificaram-se os seguintes alcalóides mediante análise combinado de GC-MS e HPLC-MS: retrorsina em S. oxyphyllus; retrorsina, usaramina e senecivernina/ senecionina em S. selloi; retrorsina, senecivernina/senecionina, integerimina e usaramina em S. madagascariensis; e integerrimina, retrorsina e senecionina em S. brasiliensis. A concentração média total de alcalóides foi mais elevada em S. brasiliensis (17,6mg/g) seguido de S. oxyphyllus (6,2mg/g), S. selloi $(1,8 \mathrm{mg} / \mathrm{g})$ e S. madagascariensis (0,6mg/g). As concentrações de alcaloides foram maiores em $2015 \mathrm{em}$ vista à 2016, provavelmente, devido a um fator ambiental comum. As espécies S. oxyphyllus e S. madagascariensis não foram previamente reconhecidas como plantas tóxicas no leste do Uruguai. Particularmente, S. oxyphyllus esteve presente em $82 \%$ das fazendas pesquisadas e ocorreu em alta densidade com concentrações relativamente elevadas de alcalóides de pirrolizidina sugerindo que S. oxyphyllus pode ser a principal espécie envolvida nos surtos relatados de seneciosis.

Palavras-chave: seneciosis, metabólitos secundários de plantas, ruminantes, intoxicação por plantas, Asteraceae.

\section{INTRODUCTION}

Plants from the genus Senecio (Asteraceae), are of worldwide distribution and are well-known for containing a wide variety of pyrrolizidine alkaloids (PA) that have chronic hepatotoxic lethal effects in cattle, horses and pigs, among other species, as well as sporadic poisoning episodes in humans (PRAKASH et al., 1999; STEGELMEIER et al., 2011). Poisoning by consumption of Senecio plants is the major problem in grazing livestock in Southern Brazil, Uruguay 
and Argentina (RIET-CORREA \& MEDEIROS, 2001; RISSI et al., 2007) and a significant cause of poisonings worldwide (BOPPRE, 2011; STEGELMEIER, 2011). Senecio plants are also a problem for agronomists as invasive species leading to deterioration of pasture quality (WATSON et al., 1994; LE ROUX et al., 2006). In Uruguay, Senecio plants are considered the most important toxic plants found in the Eastern region and the second most important toxic plants of the Western region affecting cattle (RIVERO et al., 2011; GARCÍA et al., 2016). In Eastern Uruguay there has been a significant increase of Senecio induced poisonings in grazing livestock in the last 5 years $(2010-2015)$ as evident in data collected from the Eastern Regional Veterinary Laboratory Division (DILAVE) (DUTRA et al., 2015). Before 2010, $S$. selloi was the predominant historical species involved in cattle poisoning outbreaks (DUTRA et al., 2010). Of 81 cases of poisoning by Senecio in cattle diagnosed in DILAVE (from1988 to 2016), $62(76.5 \%)$ occurred during the period $2010-2016$. Most significant localities affected were related to counties neighboring the Brazilian border (DUTRA et al., 2015). The Senecio poisoning problem has been associated with a decrease in sheep grazing (DUTRA et al., 2015) and the increased presence of emergent species of Senecio, previously nonexistent or of low prevalence (DUTRA et al., 2016). The emergence of species of Senecio has been reported in counties of Rio Grande do Sul, Brazil, near the border with Uruguay (STIGGER et al., 2014).

Senecio spp. contain many PAs, in varying concentrations and toxicity (LANGEL et al., 2011; MATTOCKS, 1986). These alkaloids are not toxic by themselves but become toxic through generation of pyrrolic metabolites produced in the liver. Toxicity is reported in all plant growth stages and persists after hay or silage production (BOPPRE, 2011). Pyrrolizidine alkaloid concentration often varies significantly depending on the species, growth stage, genotypic structure and biotic and abiotic interaction with environment (KIRK et al., 2010; LANGEL et al., 2011; STEGELMEIER, 2011).

Interest in studying the Senecio spp. and their associated pyrrolizidine alkaloids is motivated by worldwide distribution and their continued expansion into new geographical ranges, causing serious problems for livestock production and potential risk of human poisoning. Therefore, we reported on the collection of different Senecio spp. from farms of Eastern Uruguay associated with poisoning outbreaks in cattle and the associated PA content.

\section{MATERIALS AND METHODS}

\section{Plant material}

Plant material was sampled from 28 farms of Eastern Uruguay associated with poisoning outbreaks by consumption of Senecio, registered during the period 2010-2016 by Eastern Regional DILAVE. Farms belonged to the county of Cerro Largo (16) (latitude: $32^{\circ} 19^{\prime} \mathrm{S}$; longitude: $54^{\circ} 2^{\prime} \mathrm{W}$ ), Treinta y Tres (10) (latitude: $33^{\circ} 18^{\prime} \mathrm{S}$; longitude: $54^{\circ} 94^{\prime} \mathrm{W}$ ) and Tacuarembó (2) (latitude: $31^{\circ} \mathrm{S}$; longitude: $55^{\circ} \mathrm{W}$ ). From each farm, plant material from the above ground parts were collected during November and December (mid and late spring) of 2015 and 2016. Method for collection was based on the technique described by Verschave et al., (2015) as modified from Taylor (1939). Plant identification was confirmed by Ing. Agr. Mauricio Bonifacino of the Department of Botany, Agronomy Faculty, University of the Republic and deposited in their herbarium (MVFA) with the following identification on voucher specimens: MVFA Garcia 1 for S. brasiliensis, MVFA Garcia 2 for $S$. oxyphyllus, MVFA Garcia 3 for $S$. madagascariensis and MVFA Garcia 4 for $S$. selloi.

\section{Alkaloid extraction}

Dry plant material was ground in a sample mill (Cyclotec 1093). For quantitation of total pyrrolizidine alkaloids, the method previously described by Molyenuex (1979) was adapted as follows. A $1.0 \mathrm{~g}$ aliquot of the dry ground sample was placed into a $50 \mathrm{~mL}$ falcon tube and extracted with $40 \mathrm{~mL}$ of methanol by mechanical rotation for 16h. The sample was filtered and the sample residue extracted a second time with $40 \mathrm{~mL}$ of methanol for $1 \mathrm{~h}$ and filtered. Combined methanol extracts were evaporated to dryness under reduced pressure (rotoevaporation @ $40^{\circ} \mathrm{C}$ ) in a $250 \mathrm{~mL}$ round bottom flask. The extract residue in the flask was rinsed sequentially, three times each, with $2 \mathrm{~mL}$ of $1 \% \mathrm{H}_{2} \mathrm{SO}_{4}$ and $2 \mathrm{~mL}$ of dichloromethane (DCM) for a total of $6 \mathrm{~mL}$ each. The combined acid and DCM rinses were added to a $15 \mathrm{~mL}$ screw cap test tube, sealed and rotated for $5 \mathrm{~min}$ and then centrifuged. The upper aqueous layer was removed by Pasture pipette to a second test tube containing approximately $500 \mathrm{mg}$ of Zinc powder. The tube was sealed and samples mixed for $1 \mathrm{~h}$ to reduce all $\mathrm{N}$-oxides, centrifuged and the acid extract decanted to a third test tube. The $\mathrm{pH}$ of the acid extract was adjusted to 10 by addition of concentrated ammonium hydroxide and then the samples were extracted twice with chloroform $(4 \mathrm{~mL}$ and $2 \mathrm{~mL}$ extractions). The combined chloroform extracts were filtered through 
anhydrous sodium sulfate and placed into tared glass vials from which the solvent was removed by evaporation under a flow of nitrogen at $60^{\circ} \mathrm{C}$. Sample vials were placed in a vacuum oven and dried for $16 \mathrm{~h}$ at $30^{\circ} \mathrm{C}$ after which the vials were removed, allowing to equilibrate to room temperature and then weighed to obtain the total alkaloid concentration as free base alkaloid. Total alkaloid concentration was verified by NMR analysis as described previously by the addition of a known amount of 1,4-dinitrobenzene (DNB) and ${ }^{1} \mathrm{H}-\mathrm{NMR}$ analysis and integration of signals at $\delta_{\mathrm{H}} 8.5$ (DNB) and $\delta_{\mathrm{H}} 6.2$ (H-2 for macrocyclic PAs). To the dry alkaloid extract was added $1.0 \mathrm{~mL}$ of chloroform and the samples analyzed by GC-MS as previously described (Gardner et al., 2006) for qualitative analysis.

\section{HPLC-MS analysis}

For a separate qualitative analysis, a $100 \mathrm{mg}$ aliquot of the dry ground plant material was extracted with $4.0 \mathrm{~mL}$ of $0.05 \mathrm{M} \mathrm{H}_{2} \mathrm{SO}_{4}$ and $4.0 \mathrm{~mL}$ of dichloromethane (DCM). After $1 \mathrm{~h}$ the samples were centrifuged. A $1.0 \mathrm{~mL}$ aliquot of the upper aqueous layer was placed into a $1.5 \mathrm{~mL}$ snap cap Eppendorf tube containing approximately $200 \mathrm{mg}$ of zinc powder. The tubes were sealed and mixed for $1 \mathrm{~h}$ by mechanical rotation and then centrifuged. A $0.200 \mathrm{~mL}$ aliquot of the reduced acid solution was then added to a pre-rinsed Strata-XC (60mg; pre-rinse with $2 \mathrm{~mL}$ each methanol, water, and $0.05 \mathrm{M} \mathrm{H}_{2} \mathrm{SO}_{4}$ ) solid phase extraction column. The SPE columns were rinsed with $2 \mathrm{~mL}$ water and $2 \mathrm{~mL}$ methanol. The alkaloids were eluted with $3 \mathrm{~mL}$ of ammoniated methanol into a glass vial and the solvent evaporated under flow of nitrogen while heating the samples at $60^{\circ} \mathrm{C}$. Samples were prepared for analysis by the addition of $1.0 \mathrm{~mL}$ of $50 \%$ methanol in $0.1 \%$ formic acid and then analyzed by HPLC-MS using an Agilent 1260 binary HPLC pump and auto sampler coupled to a Velos Pro linear ion trap mass spectrometer operating with a heated electrospray ion source. Separation was achieved using a linear solvent gradient of acetonitrile (A) and $0.01 \%$ formic acid (B) at a flow rate of $0.300 \mathrm{~mL}$ minute with a Kinetex XB column $(2.6 \mu \mathrm{m}, 100 \times 2.1 \mathrm{~mm})$ (Phenomenex). The solvent gradient started at $3 \% \mathrm{~A}$ for $1 \mathrm{~min}$ followed by an increase to $50 \% \mathrm{~A}$ at $10 \mathrm{~min}$ and then changed back to $3 \% \mathrm{~A}$ by $11 \mathrm{~min}$ with equilibration at $3 \% \mathrm{~A}$ for $5 \mathrm{~min}$ before the next injection.

\section{Alkaloid identification}

Individual pyrrolizidine alkaloids were identified from available standard samples that included retrosine, integerrimine, usaramine and senecionine. Comparison were made as to retention time and the mass spectrum data from both GC-MS and HPLC-MS analysis.

\section{Statistical analysis}

The alkaloid data were compared for interand intra- species differences and for interspecies differences between years using analysis of variance (ANOVA). Test of Tukey-Kramer was performed to determine differences between mean of PAs content for inter- and intra-species. Significance for statistical analyses was accepted at $p<0.05$. Analyses were performed using the SAS software 9.3 (2005).

\section{RESULTS}

\section{Senecio species identified from surveyed farms}

Fifty populations of Senecio were collected from 28 farms. The species identified were: S. oxyphyllus DC, S. madagascariensis Poir, $S$. brasiliensis (Spreng.) Less., and S. selloi DC. (Table 1). The most frequently identified species

Table 1 - Senecio spp. identified from the population survey of 28 farms from three counties from eastern Uruguay during 2015 and 2016.

\begin{tabular}{|c|c|c|c|c|c|}
\hline & Farms & Species Identified & ------ & ------- & \\
\hline County Surveyed & (n) & & 2015 & 2016 & Total \\
\hline \multirow[t]{4}{*}{ Cerro Largo } & 16 & S. oxyphyllus & 8 & 8 & 16 \\
\hline & & S. selloi & 4 & 5 & 9 \\
\hline & & S. madagascariensis & 2 & 3 & 5 \\
\hline & & S. brasiliensis & 1 & 4 & 5 \\
\hline \multirow[t]{4}{*}{ Treinta y Tres } & 10 & S. madagascariensis & 4 & 2 & 6 \\
\hline & & S. oxyphyllus & 1 & 4 & 5 \\
\hline & & S. selloi & 1 & - & 1 \\
\hline & & S. brasiliensis & - & 1 & 1 \\
\hline Tacuarembó & 2 & S. oxyphyllus & - & 2 & 2 \\
\hline Totals & 28 & & 21 & 29 & 50 \\
\hline
\end{tabular}

Ciência Rural, v.48, n.2, 2018. 
was $S$. oxyphyllus $(46 \%, 23 / 50)$, followed by $S$. madagascariensis $(22 \%, 11 / 50)$, S. selloi $(20 \%$, $10 / 50)$ and $S$. brasiliensis $(12 \%, 6 / 50)$. Considering all farms $(\mathrm{n}=28)$, the relative occurrence of Senecio spp. was: S. oxyphyllus $(82 \%, 23 / 28)$, followed by S. madagascariensis $(39 \%, 11 / 28)$, S. selloi $(36 \%$, $10 / 28)$ and $S$. brasiliensis $(21 \%, 6 / 28)$. On 17 farms $(60 \%)$, there was an infestation caused by more than one Senecio spp. Five farms $(29.5 \%)$ had a mixed infestation where three species were involved, and the remaining 12 farms $(70.5 \%)$ had a two species mixed infestation. S. oxyphyllus was identified in all mixed infestations.

Pyrrolizidine alkaloids identification and concentration in Senecio plants

The major alkaloids, in their free base form, were identified for each species and included: retrorsine in $S$. oxyphyllus; retrorsine, usaramine, and senecivernine/ senecionine in S. selloi; retrorsine, senecivernine/ senecionine, integerrimine, and usaramine in $S$. madagascariensis; and integerrimine, retrorsine and senecionine in $S$. brasiliensis. Alkaloids occurred primarily as the $N$-oxide in the plant material but were converted to the free base during the extraction process to simplify analysis. The HPLC-MS profiles for the four Senecio spp. are displayed in figure 1 with the peaks assigned as to the identified alkaloids. Alkaloids identifications were confirmed by comparison to available standards and also aided by GC-MS analysis (data not shown).

The total mean alkaloid concentration was found to be highest in $S$. brasiliensis $(17.6 \mathrm{mg} / \mathrm{g})$ followed by $S$. oxyphyllus $(6.2 \mathrm{mg} / \mathrm{g}), \quad S$. selloi $(1.8 \mathrm{mg} / \mathrm{g})$ and $S$. madagascariensis contained the lowest concentration of alkaloids $(0.6 \mathrm{mg} / \mathrm{g})$ (Table 2$)$. Alkaloid concentrations were also found to be higher in 2015 vs. 2016 (Table 3).

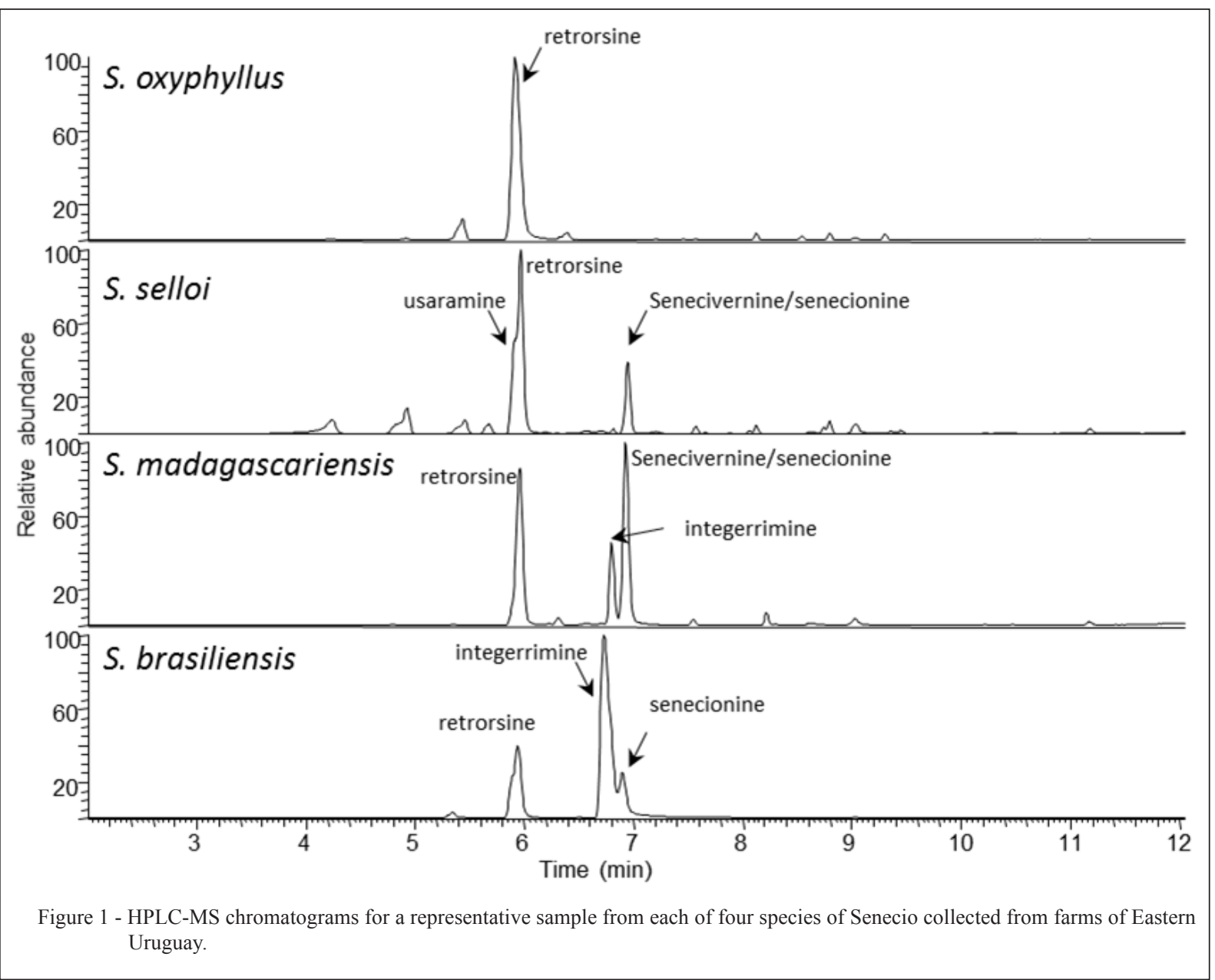

Ciência Rural, v.48, n.2, 2018. 
Table 2 - Means, standard deviation (SD) and range (minimum and maximum value) of pyrrolizidine alkaloid total concentrations, expressed in $\mathrm{mg} / \mathrm{g}$ dry matter in four species of Senecio.

\begin{tabular}{lccc}
\hline Species & Mean \pm SD $(\mathrm{mg} / \mathrm{g})$ & Range $(\mathrm{mg} / \mathrm{g})$ & $\mathrm{n}$ \\
\hline S. brasiliensis & $17.6^{\mathrm{a}} \pm 7.8$ & $11.2-32.3$ & 6 \\
S. oxyphyllus & $6.2^{\mathrm{b}} \pm 3.9$ & $2.2-15.0$ & 23 \\
S. selloi & $1.8^{\mathrm{c}} \pm 1.3$ & $0.6-4.6$ & 10 \\
S. madagascariensis & $0.6^{\mathrm{c}} \pm 0.2$ & $0.2-0.8$ & 11 \\
\hline
\end{tabular}

Different letters correspond to significant differences $\mathrm{P}<=0.05)$ in AP concentration among Senecio spp.

\section{DISCUSSION}

The eastern region of Uruguay is the primary cattle ranching area for beef production in the country. The region is characterized by open rangeland areas with increased exposure to multiple plants and the possibility of risk by grazing poisonous plants. The four species of Senecio identified appear now to be widespread in this region of Uruguay and are thus a major economic concern, as this group of plants are some of the most common plants associated with poisoning of domestic livestock (STEGELMEIER, 2011).

During the present study, two new species of Senecio were identified to now occur in the region: $S$. oxyphyllus and $S$. madagascariensis. The added presence of both species and their extensive distribution may help explain the rapid growth of outbreaks of seneciosis since 2010 (DUTRA et al., 2015). These two species, in part, have appeared to displace $S$. selloi, which was previously the main species distributed in the region (DUTRA et al., 2010). Similar scenarios occurred in Rio Grande do Sul, Brazil, neighboring Uruguay (KARAM et al., 2004; STIGGER et al., 2014). The increased occurrence on many farms observed for S. oxyphyllus and $S$. madagascariensis demonstrated the adaptative capacity of Senecio plants allowing them to spread into different geographic areas (CARVALHO et al., 2013; LE ROUX et al., 2006). It is particularly noted that $S$. oxyphyllus was the dominant plant present on all farms with mix infestation of plants from the genus Senecio. This species is also present in Rio Grande do Sul (KARAM et al., 2004). Although unknown, S. oxyphyllus could have been introduced from Brazil, since this plant was not previously present in Uruguay, and yet has a major presence in the neighboring Brazil. The rapid expansion of some Senecio spp. is not only a problem because of their toxicity but also due to the replacement of native species and the possible environmental alterations (HOL et al., 2011) by which the lands may lose future economic value.

The large variations in concentration of secondary metabolites is associated with genetic structure and several environmental factors (KIRK et al., 2010) such as stress conditions like drought, soil conditions, high temperatures and interaction with herbivores that may increase or decrease the concentration of pyrrolizidine alkaloids (PAs) in plants (JOHNSON et al., 1985; TOKARNIA et al., 2000; KARAM et al., 2004). From the current analyses, S. brasiliensis showed the highest concentration of total PAs followed by $S$. oxyphyllus, while there were

Table 3 - Mean and standard deviation (SD) of pyrrolizidine alkaloid total concentrations, expressed in mg/g dry matter, between year 2015 and 2016 in the four species of Senecio.

\begin{tabular}{lcr}
\hline Species & 2015 & 2016 \\
\hline & Mean \pm SD & Mean \pm SD \\
S. brasiliensis & $32.3(\mathrm{n}=1)$ & $14.7 \pm 3.3$ \\
S. oxyphyllus & $10.5^{\mathrm{b}} \pm 2.6$ & $3.5^{\mathrm{c}} \pm 1.2$ \\
S. selloi & $2.7^{\mathrm{d}} \pm 1.2$ & $0.9^{\mathrm{e}} \pm 0.2$ \\
S. madagascariensis & $0.5^{\mathrm{a}} \pm 0.2$ & $0.7^{\mathrm{a}} \pm 0.04$ \\
\hline
\end{tabular}

Different letters correspond to significant differences $(\mathrm{P}<=0.05)$ in $\mathrm{PA}$ concentration between years.

Ciência Rural, v.48, n.2, 2018. 
no differences between $S$. madagascariensis and $S$. selloi. The fact that there were significant differences in PA concentration intra-species between years suggested a possible common environmental factor. Total precipitation from January - June, 2015 was $339 \mathrm{~mm}$, compared $912 \mathrm{~mm}$ from the same period in 2016 (data collected from web site Portal Grass INIA). Reduced precipitation in 2016 could be factor in the decrease of PA concentrations in 2016. Other factors such as low nutrient availability (HOL, 2011) and interaction with natural enemies (HOL et al., 2004) can affect PA concentration. However, samples from this study were taken from open rangelands of the same geographic areas with similar cattle production systems for both years.

The measured alkaloid concentrations were consistent when compared to those reported for total PAs previously reported in the different Senecio spp. Plant were taken at the same phenological stage for both years, i.e. flowering. Concentration of PAs in $S$. madagascariensis varied among individual plants, ranging from 0.22 to $1.99 \mathrm{mg} / \mathrm{g}$ DW for samples collected in Hawaii (GARDNER et al., 2006) and from 0.50 to $4.0 \mathrm{mg} / \mathrm{g} \mathrm{DW}$ for samples taken in Brazil (STIGGER et al., 2014). KARAM et al. (2004) also reported variations in PA total concentration for $S$. brasiliensis (1.7 to $2.5 \mathrm{mg} / \mathrm{g}$ DW), S. oxyphyllus (0.25 to $1.96 \mathrm{mg} / \mathrm{g} \mathrm{DW})$ and S. selloi $(0.08$ to $0.21 \mathrm{mg} / \mathrm{g} \mathrm{DW})$. Other reports showed similar PA concentrations, $4.0 \mathrm{mg} / \mathrm{g}$ DW in S. oxyphyllus (LIDDELL et al., 1992) and $1.0 \mathrm{mg} / \mathrm{g}$ DW in S. selloi (MÉNDEZ et al., 1990). The high variation in PA concentrations is well documented, and has been attributed to a number of factors such as plant growth stages, season of the year as well as environmental conditions (KARAMet al., 2004).

A comparison of PAs in the Senecio spp. from the present research showed essentially the same alkaloids as previously reported. Samples of S. oxyphyllus from Brazil were reported to contain retrorsine as the major alkaloid (LIDDELL et al., 1992) and the major alkaloids identified from $S$. brasiliensis were intergerrimine and retrorsine (MÉNDEZ et al., 1990; TRIGO et al., 2003). This is consistent with the major alkaloids identified from the species investigated in this research, with the addition of senecionine in S. brasiliensis as a minor alkaloid. Senecionine and retrorsine were previously identified as the two major alkaloids in S. selloi (MÉNDEZ et al., 1990). In this study the major alkaloids were identified as retrorsine, senecionine, senecivernine and usaramine. In comparison with samples of S. madagascariensis from Hawaiian Islands and
Australia (GARDNER et al., 2006) the alkaloids retrorsine, intergerrimine, usaramine, senecivernine were as reported here; however, previously the otonecine base alkaloids (doronine, florosenine, desacetyldoronine) were much more prevalent than in those samples collected from Uruguay where they only appeared to trace amounts detected and thus not reported as major components.

\section{CONCLUSION}

Results of this research concluded that there is an increased risk of poisoning of cattle grazing farmlands heavily infested with Senecio plants. The species $S$. oxyphyllus and $S$. madagascariensis were not previously recognized as toxic plants by producers and veterinarians in Eastern Uruguay, suggesting that their appearance on these farms is a recent event as occurring in the last 5 years. Also these two plant species were reported in a higher density and more distributed in the farms surveyed, acting as invasive and expansive plants, thus, of more potential risk of exposure for livestock and loss of land value. Based on the observation of the high percentage $(23 / 28)$ of farms from which $S$. oxyphyllus was collected, the density of the plant on those farms and considering the relative high concentrations of PAs $\left(6.2 \mathrm{mg} \mathrm{g}^{-1}\right.$ dry matter) in the populations suggested it may be the main species involved in the reported outbreaks of seneciosis. It is also noted that all the major alkaloids detected among the four species of Senecio investigated here are structurally characterized as macrocyclic diesters of retronecine and;are therefore, predicted to be among the group of most toxic dehydropyrrolizidine alkaloids (Mattocks 1986). With the observed increases in Senecio plants in the rangelands and the excessive animal load on the paddock farms it may be; therefore, necessary to implement control measures to minimize livestock losses.

\section{ACKNOWLEDGEMENTS}

We want to thank all veterinary practitioners and producers who let us collect plant samples of farms.

\section{CONFLICT OF INTEREST}

The authors declare that they have no conflicts of interest.

\section{REFERENCES}

BOPPRE, M. The ecological context of pyrrolizidine alkaloids in food, feed and forage: an overview. Food Additives and Contaminants, v.28(3), p.260-281, 2011. Available from: 
$<$ https://doi.org/10.1080/19440049.2011.555085>. Accessed: May 15, 2017.

CARVALHO, S. et al. Changes in plant defense chemistry (pyrrolizidine alkaloids) revealed through high-resolution spectroscopy. ISPRS Journal of Photogrammetry and Remote Sensing, v.80, p.51-60, 2013. Available from: $<$ https://doi.org/10.1016/j.isprsjprs.2013.03.004>. Accessed: May 15, 2017.

DUTRA, F. et al. Intoxicación por Senecio selloi. Archivos Veterinarios del Este, DILAVE Regional Este-MGAP, boletín núm. 2, p.8, 2010.

DUTRA, F. et al. Intoxicación por Senecio madagascariensis en vacas. Archivos Veterinarios del Este, DILAVE Regional EsteMGAP, boletín núm. 18, p.4, 2015.

GARCÍA, J.A. et al. Análisis retrospectivo de intoxicaciones asociadas a plantas tóxicas, micotoxinas y otros compuestos en bovinos de la región este de Uruguay (1994-2015). Conference communication in XLIV Jornadas Uruguayas, Buiatría, Paysandú, Uruguay, p.148, 2016.

GARDNER, D. et al. Pyrrolizidine alkaloids in Senecio madagascariensis from Australia and Hawaii and assessment of possible livestock poisoning. Biochemical Systematics and Ecology, v.34, p.736-744, 2006. Available from: <https://doi. org/10.1016/j.bse.2006.05.010>. Accessed: May 15, 2017.

HOL, W.H.G. et al. Root damage and aboveground herbivory change concentration and composition of pyrrolizidine alkaloids of Senecio jacobaea. Basic Applied Ecology, v.5, p.253-260, 2004. Available from: <https://doi.org/10.1016/j.baae.2003.12.002>. Accessed: May 15, 2017.

HOL, W.H.G. The effect of nutrients on pyrrolizidine alkaloids in Senecio plants and their interactions with herbivores and pathogens. Phytochemistry Reviews, v.10, p.119-126, 2011. Available from: <https://doi.org/10.1007/s11101-010-9188-7>. Accessed: May 15, 2017.

JOHNSON, A.E. et al. Chemistry of Toxic Range Plants. Variation in Pyrrolizidine Alkaloid Content of Senecio, Amsinckia, and Crotalaria species. Journal of Agricultural and Food Chemistry, v.33(1), 1985. Available from: <https://doi.org/10.1021/ jf00061a015>. Accessed: May 15, 2017.

KARAM, F.S.C. et al. Epidemiological aspects of seneciosis in southern Rio Grande do Sul, Brazil. Pesquisa Veterinária Brasileira, v.24(4), p.191-198, 2004. Available from: <https://doi.org/10.1590/ s0100-736x2004000400004>. Accessed: May 15, 2017.

KIRK, H. et al. Species by environment interactions affect pyrrolizidine alkaloid expression in Senecio jacobaea, Senecio aquaticus, and their hybrids. Journal of Chemical Ecology, v.36 p.378-387, 2010. Available from: <https://doi.org/10.1007/ s10886-010-9772-8>. Accessed: May 12, 2017.

LANGEL, D. et al. The evolution of pyrrolizidine alkaloid biosynthesis and diversity in the Senecioneae. Phytochemistry Reviews, v.10, p.3-74, 2011. Available from: <https://doi. org/10.1007/s11101-010-9184-y>. Accessed: May 15, 2017.
LE ROUX, J.J. et al. Resolving the native provenance of invasive fireweed (Senecio madagascariensis poir.) in the Hawaiian Islands as inferred from phylogenetic analysis. Diversity and Distributions, v.12, p.694-702, 2006. Available from: <https://doi.org/10.1111 /j.1366-9516.2006.00271.x>. Accessed: May 12, 2017.

LIDDELL, J.R. et al. Pyrrolizidine alkaloids from Senecio oxyphyllus, a brazilian poisonous plant. Biochemical Systematics and Ecology, v.20(4), p.393, 1992. Available from: $<$ https://doi. org/10.1016/0305-1978(92)90052-f>. Accessed: May 15, 2017.

MATTOCKS, A.R. Chemistry and toxicology of pyrrolizidine alkaloids. Academic press, London, 1986. Available from: $<$ https:// doi.org/10.1016/s0031-9422(00)84554-9>. Accessed: May 5, 2017.

MÉNDEZ, M.C. et al. Experimental poisoning of cattle and chicks by five Senecio species. Pesquisa Veterinária Brasileira, v.10(3/4), p. 63-69, 1990

PRAKASH, A.S. et a. Pyrrolizidine alkaloids in human diet Mutation research, v.443, p.53-67, 1999. Available from: <https:// doi.org/10.1016/S1383-5742(99)00010-1>. Accessed: May 10, 2017.

RIET-CORREA, F., Medeiros, R.M.T. Intoxicações por plantas em ruminantes no Brasil e no Uruguai: importânciaeconômica, controle e riscos para a saúde pública. Pesquisa Veteterinária Brasileira, v.21, p.38-42, 2001. Available from: <https://doi.org/10.1590/ s0100-736x2001000100008>. Accessed: May 22, 2017.

RISSI, D.R. et al. Plant and plant-associated mycotoxins poisoning in cattle in Rio Grande do Sul, Brazil: 461 cases. Pesquisa Veterinária Brasileira, v.27(7), p.261-268, 2007. Available from: <https://doi. org/10.1590/s0100-736x2007000700002>. Accessed: May 15, 2017.

RIVERO, R. et al. Toxic plants and mycotoxins affecting cattle and sheep in Uruguay. En: Riet-Correa F, Pfister J, Schild AL, Wierenga TL. Poisoning by plants, mycotoxins, and related toxins. London, p.25-34, 2011.

STEGELMEIER, B.L. Pyrrolizidine alkaloid-containing toxic plants (Senecio, Crotalaria, Cynoglossum, Amsinckia, Heliotropium, and Echium spp.). Food animal practice, v.27(2), p.419-428, 2011. Available from: <https://doi.org/10.2458/azu rangelands_v31i1_gardner2>. Accessed: May 15, 2017.

STIGGER, A.L. et al. Senecio madagascariensis Poir. (Asteraceae): a new cause of seneciosis in cattle in Southern Brazil. Pesquisa Veterinária Brasileira, v.34(9), p.851-855, 2014. Available from: $<$ https://doi.org/10.1590/s0100-736x2014000900008>. Accessed: May 22, 2017.

TRIGO, J.R. Chemotaxonomic value of pyrrolizidine alkaloids in southern Brazil Senecio (Senecioneae: Asteraceae). Biochemical Systematics and Ecology, v.31, p.1011-1022, 2003. Available from: <https://doi.org/10.1016/s0305-1978(03)00038-3>. Accessed: May 15, 2017.

TOKARNIA, C.H. Plantas hepatotóxicas. In: Tokarnia $\mathrm{CH}$, Döbereiner J, Peixoto PV (ed.) Plantas Tóxicas do Brasil. Editora Helianthus, Rio de Janeiro, 310p, 2000.

WATSON, R. et al. Fireweed. Agfact, 2nd edn, NSW Agriculture. Australia, 1994. 